PUBLIPRENEUR POLIMEDIA: JURNAL ILMIAH

JURUSAN PENERBITAN POLITEKNIK NEGERI MEDIA KREATIF

Vol. 7, No. 1, July 2019

Submitted: 5 July 2019

Revised: 15 July 2019

Accepted: 30 July 2019

\title{
ANALYSIS OF PAPER ABSORPTION FROM DRIED LEAVES AS POTENTIAL OF FUTURE ORGANIC SANITARY PADS
}

\author{
Handika Dany Rahmayanti1 ${ }^{*}$, Septia Ardiani2, Nurul Akmalia ${ }^{3}$, dst. \\ 1Prodi Teknik Kemasan, Politeknik Negeri Media Kreatif Jakarta \\ 2 Prodi Teknik Kemasan, Politeknik Negeri Media Kreatif Jakarta \\ 3 Prodi Penerbitan, Politeknik Negeri Media Kreatif Jakarta \\ E-mail: handikadany@polimedia.ac.id', septiaardianiphysics@gmail.com², \\ nakmalia6@gmail.com³
}

\begin{abstract}
The use of waste as well as unused goods becomes something that has a sales value which is very necessary to preserve the environment. One example is the use of dry leaf waste which can be transformed into goods of economic value to the people who use them. The transformation of dry waste into pulp is one of the efforts that can be made to overcome the waste problem. The pulp from the dried leaf waste can then be turned into paper which can then be used as an alternative to sanitary pads.

Keyword: garbage, dry leaves, paper, absorption and sanitary pads
\end{abstract}

\section{ANALISIS DAYA SERAP KERTAS DARI SAMPAH DAUN KERING SEBAGAI POTENSI BAHAN PEMBALUT ORGANIK MASA DEPAN}

ABSTRAK Pemanfaatan sampah maupun barang tidak terpakai menjadi sesuatu yang memiki nilai jual yang sangat diperlukan untuk melestarikan lingkungan. Salah satu contohnya adalah dengan pemanfaatan sampah daun kering yang dapat diolah menjadi barang yang memiliki nilai ekonomi bagi masyarakat yang memanfaatkannya. Pengolahan sampah daun kering menjadi pulp merupakan salah satu usaha yang dapat dilakukan untuk mengatasi permasalahan akan sampah. Pulp dari sampah daun kering kemudian dapat diolah menjadi kertas serap yang nantinya dapat digunakan sebagai alternatif bahan baku pembalut.

Kata kunci: sampah, daun kering, kertas, daya serap dan pembalut

\section{PENDAHULUAN}

Apa yang pertama kali dicari oleh perempuan ketika datang bulan? Sudah pasti pembalut. Saat ini, banyak merek pembalut wanita yang menawarkan berbagai kelebihan. Mulai dari aroma, warna dan bentuknya. Belum lagi iklan di media massa yang semakin gencar. Tentunya hal itu membuat sebagian orang bingung menentukan pilihan. Tidak semua pembalut aman bagi kesehatan organ intim kaum perempuan. Dan tahukah anda bahwa pembalut perempuan ternyata bisa sebagai penyebab tumbuh dan berkembangnya kanker serviks.
Pembalut wanita adalah produk sekali pakai. karena itulah para produsen mendaur ulang bahan baku kertas bekas dan pulp, menjadikannya bahan dasar untuk menghemat biaya. Bahan bakunya mulai dan kertas koran, kardus, karton bekas, penuh dengan bakteri dan kumankuman, serta bermacam pewarna sintetis, dan berbau. Dalam proses daur ulang, banyak zat kimia digunakan untuk proses pemutihan kembali. Gambar 1 berikut ini menunjukkan proses daur ulang kertas bekas menjadi bahan dasar pembalut. 


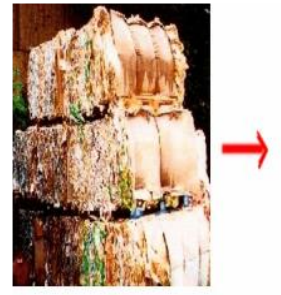

Bahan Baku Kertas Bekas

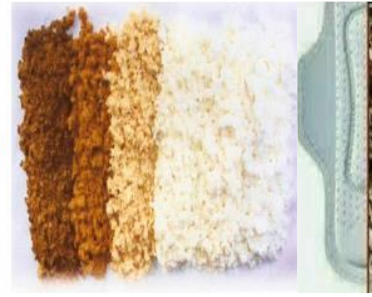

Kertas Bekas setelah didaur ulas diputihkan dengan Bahan Kimi mengandung Dioxin

Gambar 1. Proses daur ulang kertas bekas menjadi bahan dasar pembalut.

Zat kimia juga digunakan untuk proses sterilisasi kuman-kuman pada kertas bekas serta pembuangan bau. Apabila darah haid jatuh keatas permukaan pembalut wanita, zat dioxin akan dilepaskan melalui proses penguapan. pertamanya akan mengenai permukaan vagina/vulva, kemudian diserap ke dalam rahim melalui saluran serviks, kemudian masuk ke dalam uterus, kemudian melewati Fallopian tubes, dan berakhir di ovary/rahim. Oleh karena itu diperlukan penelitian untuk mencari alternatif bahan baku pembalut yang aman, murah serta berdaya serap tinggi. Melalui penelitian ini kami akan membuat bahan dasar pembalut menggunakan bahan organik yakni sampah daun kering.

Sampah daun kering dapat diproses menjadi pulp kemudian dapat diolah menjadi kertas serap yang nantinya dapat digunakan sebagai alternatif bahan baku pembalut. Hasil dari penelitian ini diharapkan mampu menjadi alternatif bahan dasar pembalut organik yang aman serta berdaya serap tinggi sekaligus menanggulangi permasalahan sampah daun kering yang biasanya hanya dibuang begitu saja.

\section{METODE PENELITIAN}

Bahan yang digunakan pada proses pembuatan pulp dari sampah daun kering adalah sampah daun kering, $\mathrm{NaOH}$, tepung tapioka, kaporit dan aquades. Alat yang digunakan dalam penelitian ini adalah, gunting, neraca digital, pengaduk, gelas ukur, blender,screen sablon, panci. Sedangkan alat yang digunakan untuk pengujian daya serap adalah beker glass, kertas saring stopwatch, penjepit dan aquades. Beberapa merek pembalut di pasaran juga digunakan pada penelitian ini sebagai pembanding. Metode penelitian digambarkan pada bagan berikut ini:

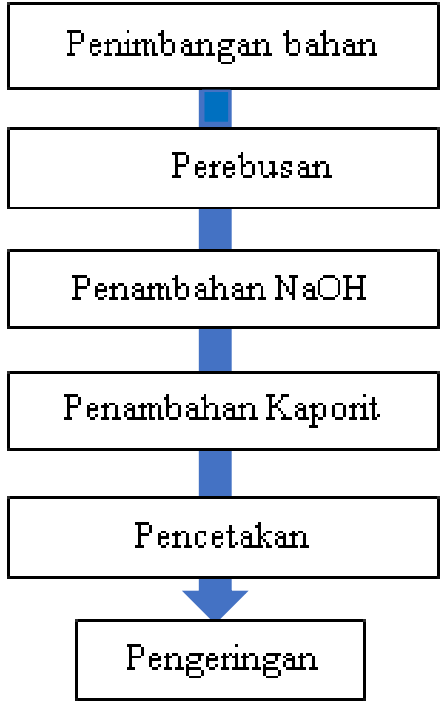

Gambar 2. Alur Penelitian

\section{HASIL DAN PEMBAHASAN}

Pembuatan bubur selulosa atau pulping yang berbahan baku limbah daun menggunakan cara mekanis. Penambahan bahan perekat pada penggunaan kertas sampah daun kering dilakukan pada saat bubur kertas (pulp) belum dibentuk menjadi lembaran tisu dengan cara mencampurkan tepung tapioka.

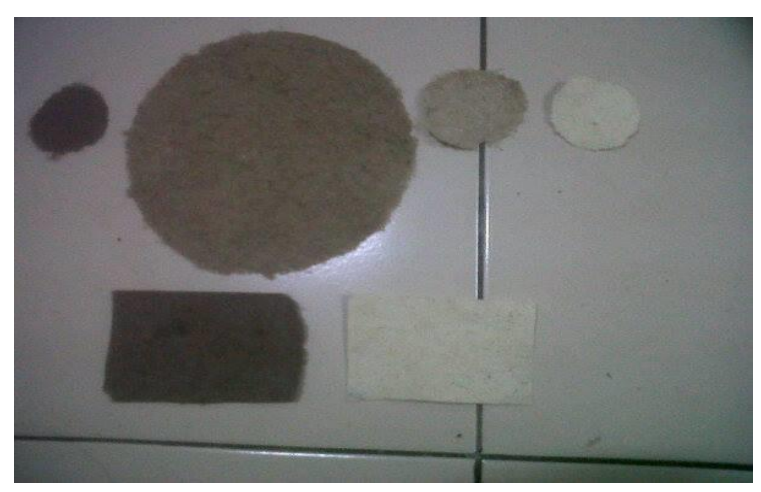




\section{Gambar 3. Sampel}

Tujuan dari variasi konsentrasi $\mathrm{NaOH}$ dalam percobaan adalah untuk untuk mengetahui pengaruh konsentrasi $\mathrm{NaOH}$ dengan tapioka terhadap rapat massa (densitas) dan daya serap bahan dasar pembalut yang akan dibuat. Untuk menentukan nilai rapat massa (densitas) masing-masing sampel bahan dasar pembalut dari sampah daun kering menggunakan persamaan berikut

$$
p=\frac{m}{V}
$$

Nilai $\rho$ merupakan nilai rapat massa (densitas) sampel bahan dasar pembalut dari sampah daun, $m$ adalah massa sampel bahan dasar pembalut dari sampah daun sedangkan $V$ merupakan volume nya.

Nilai rapat massa (densitas) masing-masing sampel bahan dasar pembalut dari sampah daun untuk tiap variasi konsentrasi $\mathrm{NaOH}$ menunjukkan nilai yang berbeda-beda. Lihat pada gambar 4 .

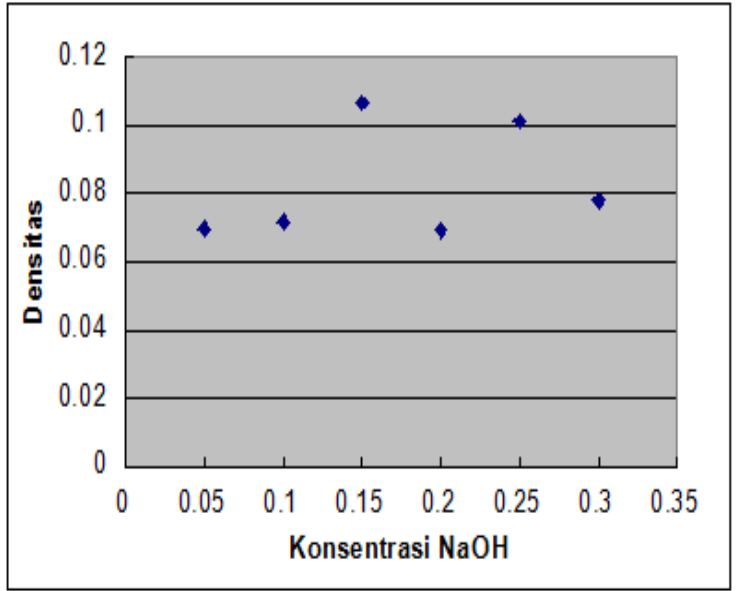

Gambar 4. Grafik Hubungan antara konsentrasi $\mathrm{NaOH}$ terhadap densitas sampel
Berdasarkan data diatas didapatkan hasil yaitu pada konsentrasi 0,05 M didapatkan nilai densitasnya adalah 0,0697 $\mathrm{gr} / \mathrm{cm}^{3}$., untuk konsentrasi 0,1 M nilai densitasnya adalah 0,071 $\mathrm{gr} / \mathrm{cm}^{3}$, konsentrasi $0,15 \mathrm{M}$ nilai densitasnya adalah $0,1 \mathrm{gr} / \mathrm{cm}^{3}$, konsentrasi 0,2 M adalah 0,0691 $\mathrm{gr} / \mathrm{cm}^{3}$, konsentrasi $0,25 \mathrm{M}$ nilai densitasnya adalah $0,101 \mathrm{gr} / \mathrm{cm}^{3}$ sedangkan pada konsentrasi 0,3 M nilai densitasnya adalah 0,078 $\mathrm{gr} / \mathrm{cm}^{3}$

Berdasarkan hasil penelitian, variasi konsentrasi $\mathrm{NaOH}$ tidak terlalu mempengaruhi densitas sampel bahan dasar pembalut dari sampah daun. Karena jika semakin banyak $\mathrm{NaOH}$ yang ditambahkan, maka densitas yang dihasilkan akan naik, tetapi cuma sampai pada konsentrasi 0,05-0,15M. Setelah penambahan konsentrasi $\mathrm{NaOH}$ pada konsentrasi 2 - 3M densitasnya menjadi naik turun, tidak stabil. Hal ini disebabkan karena pada pengukuran volume didapatkan tebal sampel bahan dasar pembalut dari sampah daun yang dibuat untuk uji densitas ini tidak sama untuk tiap sampel dengan variasi konsentrasi $\mathrm{NaOH}$. Karena ketidakmeratanya saringan yang digunakan untuk menyaring pulp (bahan dasar kertas) yang sudah jadi sehingga mengakibatkan ketebalan yang berbeda tiap sampel sehingga dihasilkan densitas yang beragam dan kurang sesuai dengan teori.

Setelah dilakukan pengujian terhadap rapat massanya (densitas) selanjutnya diukur daya serap sampel bahan dasar pembalut dari sampah daun. Pengukuran daya serap dilakukan dengan cara emnimbang sampel pada keadaan kering setelah itu menimbang sampel dalam keadaan basah kemudian didapatkan daya serapnya. Dari penelitian ini diukur pula tingkat daya serap bahan dasar pembalut yang telah beredar dipasaran. Dengan mengambil 6 
sampel berbagai merek yang berbeda. Lihat pada gambar 5.

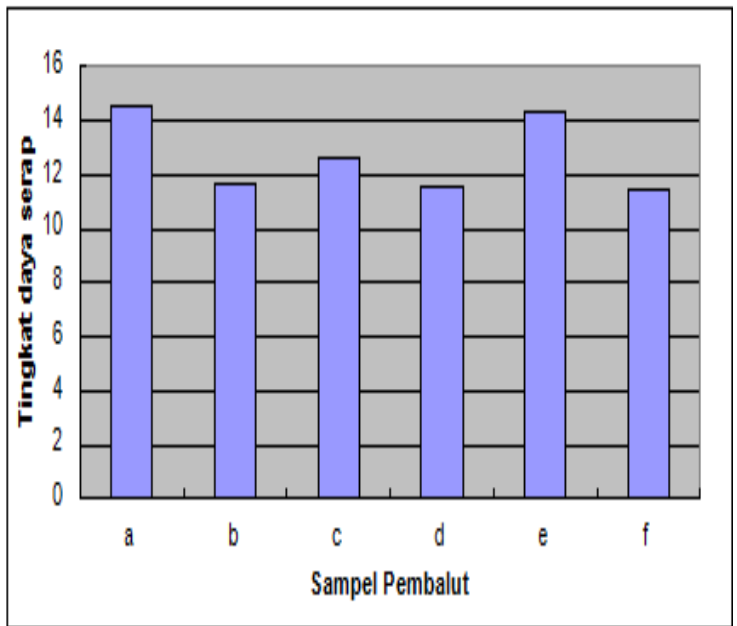

Gambar 5. Grafik tingkat daya serap bahan dasar pembalut bergai merek yang beredar

Sedangkan untuk nilai daya serap sampel bahan dasar pembalut dari sampah daun nilainya dapat dilihat pada gambar 6 seperti berikut ini

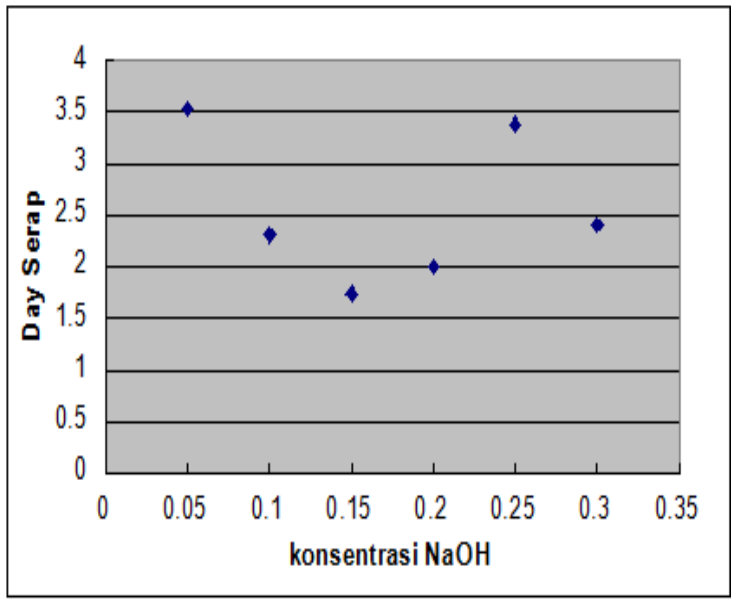

Gambar 6. Grafik hubungan antara konsentrasi $\mathrm{NaOH}$ dengan daya serap sampel

Dari grafik diatas menunjukkan bahwa antara tingkat daya serap sampel bahan dasar pembalut dari sampah daun jika dibandingkan dengan tingkat daya serap yang telah beredar di pasaran nilainya sangat berbeda. Bahan dasar pembalut yang ada dipasaran memiliki tingkat daya serap lebih tinggi bila dibandingkan dengan sampel-sampel bahan dasar pembalut dari sampah daun yang telah dibuat. Hal ini terjadi dikarenakan tingkat ketebalan sampel yang dibuat dibandingkat bahan dasar yang telah bererdar juga berbeda sehingga mengakibatkan daya serapnya lebih tinggi. Semakin tebal maka daya serapnya terhadap air akan lebih tinggi. Oleh karena itu, perlu pengkajian ulang dan dilakukan penelitian lebih lanjut guna menghasilkan sampel bahan dasar pembalut dari sampah daun dengan daya serap yang tinggi.

Pada grafik hubungan antara variasi konsentrasi $\mathrm{NaOH}$ dengan pengukuran daya serapnya didapatkan hasil yang tidak stabil. Pada variasi konsentrasi $\mathrm{NaOH}$ 0,050,15M didapatkan tingkat daya serap sampel bahan dasar pembalut dari sampah daun mengalami penurunan. Namun pada variasi konsentrasi $\mathrm{NaOH}$ 0,2-0,3M tingkat daya serap sampel tidak stabil. Hal ini dikarenakan karena parameter proses. Dibutuhkan kontrol selulosa yang tepat.

Setelah dilakukan 2 uji sifat fisis, didapatkan hasil bahwa rapat massa (densitas) bahan dasar pembalut dari sampah daun kering berbanding terbalik dengan nilai daya serapnya. Apabila densitasnya tinggi maka daya serap bahan dasar pembalut dari sampah daun nilainya rendah. Begitu pula sebaliknya, apabila densitasnya rendah maka daya serap bahan dasar pembalut dari sampah daun nilainya tinggi.

Hal ini sudah sesuai dengan teori yang sudah ada yaitu daya serapnya nilai rapat massa/densitas suatu bahan akan berbanding terbalik dengan tingkat daya serapnya. Semakin tinggi kerapatan massa/densitas suatu bahan makan daya serap terhadap air akan semakin rendah. Begitu pula sebaliknya, apabila nilai rapat 
massa suatu bahan rendah maka tingkat daya serapnya akan tinggi

\section{SIMPULAN}

Telah berhasil dibuat pembalut berbasis sampah daun. Pengkajian mengenai sifat fisis seperti daya serap dan rapat massa (densitas) dari pembalut merupakan fokus dari penelitian ini. Pada penelitian ini didapatkan hasil bahwa rapat massa (densitas) bahan dasar pembalut dari sampah daun kering berbanding terbalik dengan nilai daya serapnya. Apabila densitasnya tinggi maka daya serap bahan dasar pembalut dari sampah daun nilainya rendah, begitu pula sebaliknya.

\section{DAFTAR PUSTAKA}

Halimatuddahliana dkk. 2013. Daya Serap Air dan Kandungan Serat (Fiber Content) Komposit Poliester tidak jenuh (Unsaturased Polyester) Berpengisi Serat Tandan Kosong Sawit dan Selulosa. Medan. Universitas Sumatra Utara

Hairul Abral. 2010. Studi Kekuatan Tarik dan Sifat Fisik Serat Cyathea contaminans Sebelum dan Setelah Mengalami Perlakuan Alkali NaOH. Padang. Universitas Andalas

Wakhid Indra Kusuma dkk. 2013. Pengaruh Konsentrasi $\mathrm{NaOH}$ yang Berbeda Terhadaap Mutu Agar Rumput Laut Gracilaria verrucos. Semarang. Universitas Diponegoro

Aminah Asngad dkk. 2012. Pemanfaatan Rumput Gajah (Pennisetum Purpureum) Untuk Pembuatan Kertas Melalui Chemical Pulping Menggunakan $\mathrm{NaOH}$ dan $\mathrm{Na}_{2} \mathrm{CO}_{3}$. Surakarta. Universitas Negeri Semarang

Kuncoro Diharjo. 2013. Pengaruh Perlakuan Alkali terhadap Sifat Tarik Bahan Komposit Serat Rami-Polyester. Surakarta. Universitas Negeri Sebelas Maret

H.P.S. Abdul Khalil dkk. 2006. Chemical Composition, Anatomy, Lignin
Distribution, and Cell Wall Structure of Malaysian Plant Waste Fibers. bioresources

Waham Asheir Laftah. 2015. Chemical Pulping of Waste Pineapple Leaves Fiber for Kraft Paper Production. Malaysia. Universitas Teknologi Malaysia.

Godliving Y.S.Mtui. 2009. Recent Advances in Pretreatment of Lignocellulosic Wastes and Production of Value Added Products. Brunei. Darusalam Universitas Darrusalam

Sweeta Akbari.2014. Synthesis and Characterization of Medium Density Fiber Board By Using Mixture Of Natural Rubber Latex and Starch as an Adhesive.India. Indian Academy of Wood Science.

Callister, William D., Rethwisch, Davit G. 2009. Materials Science and Engineering an Introduction. USA: United of America

Izaak Donald Franklin, Fentje A.Rauf, Romels Lumintang.2013. Analisis Sifat Mekanik dan Daya Serap Material Komposit Serat Rotan. Jurnal Ilmiah Teknik Lingkungan Vol.2 No. 2

Sucipto, Wijana, S,Wahyuningtyas, E. 2009. Optimasi Penggunaan $\mathrm{NaoH}$ dan Tapioka pada Produksi Kertas Seni dari Pelepah Pisang. Jurnal Teknologi Pertanian. 10 (1) : 46 - 53

Van Vlack, L. H., 1994, terjemahan Japrie, S. Ilmu dan Teknologi Bahan,Edisi kelima,Erlangga,Jakarta (Gibson 1994). Principle of Composites materials225 